\title{
Evaluation of Financial Condition of Private Commercial Banks in Bangladesh: A Comparative Study
}

\section{Taposh Kumar Neogy}

Assistant Professor, Department of Business Administration, Institute of Business Administration (under National University), Rajshahi, BANGLADESH

\begin{abstract}
The study mainly evaluates the financial condition of Private Commercial Banks in Bangladesh during the years from 2004 to 2008. The Sample banks have been able to earn profit and the percentage of net profit is satisfactory during the study period. Return on total assets ratio and return on equity ratio of the sample banks are also satisfactory during the period under study. The financial condition of the sample banks is satisfactory during the period under study.
\end{abstract}

Key Words: Commercial Bank, Financial Condition, Bangladesh JEL Classification Code: M41

\section{INTRODUCTION}

Bangladesh is one of the most poor and slow growing economic countries in the world. Commercial Banks especially private commercial banks in Bangladesh have been playing significant role to the overall development process of Bangladesh. For the attainment of higher levels of economic development, developing countries are trying to achieve and maintain high rates of economic growth. Bangladesh is no exception to this. On the domestic front the economy has shown reasonable stability in terms of most macro economy indicators and exhibited higher growth potential on the external front, Bangladesh exposure contagion effects of the global financial markets has been low and the country's financial sector remained largely immune to the recent global financial turmoil. Economic development entails that banking and economic development is closely interrelated. Commercial bank as the financial services industry is playing a vital role in the service sector of Bangladesh. Actually the banking systems operated as full service industry is performing directly or indirectly all financial services. Private commercial banks mobilize savings and make it advances to investors and by this process make profit. As they deal with public money, their form of business is different from others. Banks must refund public money when they demand, either it makes profit or not ( Saha et. al. , 2007). National Bank Limited was incorporated in Bangladesh as a public limited company with limited liability as on 15 March 1983 under Companies Act, 1913 (Companies Act, 1994) to carry out banking business. It obtained license from Bangladesh Bank for carrying out banking business on 22 March 1983. The Bank has been carrying out its banking activities through its one hundred and six branches over the country. The Bank is listed 
with Dhaka Stock Exchange Limited and Chittagong Stock Exchange Limited (Annual Report of National Bank Limited, 2008). Besides, Jamuna Bank Limited was incorporated in Bangladesh on $2^{\text {nd }}$ April in the period 2001 as a public Limited Company under Companies Act, 1994. The Bank within the stipulations lay down by the Bank Companies Act, 1991 and directives as received from Bangladesh Bank and applicable to it from time to time provide all types of commercial banking services. The Bank has thirty nine branches (including two Islamic Banking Branches), with no overseas branches as at December 31, 2008 (Annual Report of Jamuna Bank Limited, 2008).

\section{ObJective Of the Study}

The main objective of the study is analyzing the financial condition of the private commercial banks in Bangladesh during the study period from 2004 to 2008.

\section{Methodology of the Study}

The researches have Company two private commercial banks for the study such as National Bank Limited (hers in after Sample \# 1) and Jamuna Bank Limited (here in after Sample \# 2). The present study is based on secondary data. The main source of secondary data is the annual reports of the Sample Banks, other publications and related bodies. Moreover, various published and unpublished literatures related to the study have been included to develop a conceptual framework of the research study. In this regard, data are collected from income statements, balance sheet, cash flow statement and owner's equity statement of the Sample Banks. To analyze the collected data we have used mean value, standard deviation, coefficient of variation simple regression, multiple regression and $t$ test. T-test is based on t-distribution and is considered an appropriate test for judging the significance of a sample mean or for judging the significance of difference between the means of face samples in case of small samples when population variance is not known. It is the technique to test the hypotheses about the mean of a normal population whose standard deviation is unknown.

$$
\mathrm{t}=\frac{\overline{\mathrm{X}}-\mu}{\mathrm{S}_{\mathrm{e}}}
$$

Where, $\begin{aligned} \bar{X} & =\text { Population mean } \\ \mu & =\text { Sample mean } \\ S_{e} & =\text { Standard error of the mean }\end{aligned}$

\section{Conceptual Framework}

The profit margin is a measure of overall profitability. Profit margin varies with the disproportionate variations in sales revenue in comparison to cost or the vice-versa. The profit margin can be increased either by making up prices of by reduction in costs or by both. The bank should earn profits to survive and grow over a long period of time. Profits are essential, but it would be wrong to assume that every action initiated by management of a bank should be aimed at maximizing profits, irrespective of concerns for customers, employees, suppliers or social consequences. It is unfortunate that the word profit is looked upon as a term to abuse since some firms always want to maximize profits at the cost of employees, customers and society. Except such infrequent cases, it is a fact that sufficient profits must be earned to sustain the operations of the business, to be able to obtain funds from investors for expansion and growth and to contribute towards the social 
overheads for the welfare of the society. Profit is the difference between revenues and expenses over a period of time. Profit is the ultimate output of a company, and it will have no future if it fails to make sufficient profits. Therefore, the financial manager should continuously evaluate the efficiency of the bank in term of profits. The profitability is calculated to measure the operating efficiency of the bank. Besides management of the bank, creditors and owners are also interested in the profitability of the bank. Creditors want to get a required rate of return on their investment. This is possible only when the bank earns enough profits. Profitability can be analyzed either on the basis of operating profits or in regard to net profit. Operating profit reflects profit from the main business for which the corporation or enterprises was launched and offers the most reliable measure for the long-term perspective. On the other hand, the net profit reflects the net profit of operating and non-operating income. It equips the analyst with the most reliable measure of profitability from the short-term point of view.

\section{REVIEW OF RELATEd LiteratuRES}

Rahman and Belal (1991), wrote an article on Profitability of Urea Fertilizer Sample Companies in Bangladesh: A Comparative Study. The objectives of the study have been to calculate the relevant profitability ratios to measure the profitability of the Company samples and to measure the profitability trend of the Company samples over the period under study. The authors have got their study that the average gross profit ratio and operating profit ratios are satisfactory while the return on fixed capital and return on total assets are not satisfactory. The average returns on capital employed and return on net worth are also not satisfactory.

Husanin (1990), wrote an article on Profitability Analysis in Mechanized Inland Water Transport of Bangladesh. Inland water transport, being the cheapest mode of transport enjoys certain advantages over others. During the recent years, however, certain problem associated with this mode of transport has made it less profitable that before. While the government wants an expansion of private sector and a reduction or static position in the public sector, investors in this sector seems to be reluctant to come forward with their capital for investment. The reason is obvious, while the Govt. is not much conceded about monetary profit; private entrepreneurs are a reduction in the private sector. The reason for reduction of profitability is the increased cost of operation coupled with disproportionate rise in freight rates and fares. Depreciation cost over the years has also increased due to a manifold rise in the capital cost of vessels. Under this situation, it is very difficult to salvage this sector from its present decaying condition. The planners in our country should find a way out and save this sector of transport from a virtual closure.

Noor et. al. (2000), conducted an article on Profitability of BRAC Financing Micro Enterprises: A Case Study of Kushtia District. Micro enterprises have made remarkable changes in rural economy through micro credit programs which are providing credit and other developmental services to poor, in a non traditional way. This study aims at measuring the profit rates made by village organizations members once they have invested in various types of projects financed by BRAC. The study also attempts to explore the impact of training on the profit rates. Profit of different projects has been computed considering employees with adequate training and employees with inadequate training respectively. It is seen that the former show higher profitability than the later but the difference was not significant. It is also found that poultry and fishery projects show the most substantial contribution to household income. The study has modest attempt to find out the reasons for the variations of profits in different projects and out lines some recommendations to the better management to raise borrowers profit rates. 
Kabir (2000), wrote an article on Cost Behavior and Profitability: A Study on Some Company Sugar Mills in Bangladesh. Cost behavior and profitability of the sugar mills in Bangladesh depend mainly on volume of production, capacity utilization, recovery rate, volume of sales, tax burden, interest cost, cane price, overstaffing, development duties, support services etc. Unless there are facilities for full capacity utilization in each of the sugar mills, cost control efforts, timely sales of available sugar at the prescribed price rates, there in very little scope to arrive at break-even position for any of the sugar mills. The basic assumptions of marginal costing do not prevail at the cost elements. Besides, high fixed cost creates anomalies in cost behavior. Mill authorities and BSFIC need to provide more incentives like liberal credit facilities, high yielding seeds, fertilizers, insecticides etc. for cultivation of quality cane and ensure its availability to the mills. Pricing strategies also need to be changed in view of the nature of cost element. Application of marginal costing, standard costing and budgetary control techniques may unveil the inherent weaknesses and changes in cost behavior.

Ali (2000), has been written an article on Capacity Utilization and Profitability of Sugar Mills in Bangladesh. The objectives of study are (a) to find out the production capacity utilization and its impact on production cost of the Company sugar mills, (b) to determine the influencing factors of production capacity of the Company sugar mills, (c) to assess the trend of production capacity utilization of the Company sugar mills, (d) to show the correlation of production capacity with variable and fixed costs of the Company sugar mills and (e) to put forward some suggestions on the basis of findings of the study. Production capacity is the ratio of actual production to installed capacity of production expressed in percent. Production capacity of sugar mills depends on availability of quality cane. Unutilized production capacity increases the fixed production cost per unit of production cost per unit of production. Adequate supply of better quality of sugarcane to the sugar cost per unit will come down and profit will increase or loss will come down in the Company sugar mills in Bangladesh. Production capacity utilization depends on recovery rates and supply of sugarcane to the sugar mills and recovery rate depends on to some extent on better quality of sugarcane.

\section{ANALYSIS AND FINDINGS}

\section{Table \# 1}

Table showing the interest income of the Sample Banks during the study period (Tk in million)

\begin{tabular}{|c|c|c|c|c|}
\hline Financial Year & Sample \# 1 & Sample \# 2 & $\mathrm{t}$ values & SL \\
\hline 2004 & 2341.43 & 1004.35 & \multirow{8}{*}{ (5.738) } & \multirow{8}{*}{0.005} \\
\hline 2005 & 2512.17 & 1374.38 & & \\
\hline 2006 & 3674.32 & 2095.51 & & \\
\hline 2007 & 4288.80 & 2230.26 & & \\
\hline 2008 & 5787.92 & 2890.65 & & \\
\hline Average & 3720.91 & 1919.03 & & \\
\hline SD & 1410.78 & 742.52 & & \\
\hline $\mathrm{CV}$ & 37.91 & 38.69 & & \\
\hline
\end{tabular}

(Source: Annual Reports of the Sample Banks from 2004 to 2008)

Table - 1 show that the average interest income of the sample banks are 3720.91 and 1919.03 respectively during the period under study. The standard deviations of interest income of the sample banks are 1410.78 and 742.52 and the co-efficient of variations are 37.91 and 38.63 respectively during the period study period. In order to see whether there 
is any significant difference between the interest income of the sample banks and we have conducted paired sample $t$ test using SPSS. The result shows that $t$ value is (5.738) which is significant at 0.005 levels. This indicates that there is significant difference between the interest incomes of the sample banks. We observe from the Table that the interest income of the Sample \# 1 is higher than the Sample \# 2 during the period under study.

Table \# 2

Table showing the non-interest income of the Sample banks during the study period

(Tk in million)

\begin{tabular}{|c|c|c|c|c|}
\hline Financial Year & Sample \# 1 & Sample \# 2 & t values & SL \\
\hline 2004 & 1369.81 & 153.74 & \multirow{8}{*}{$(6.721)$} & \multirow{8}{*}{0.003} \\
\hline 2005 & 1690.32 & 249.59 & & \\
\hline 2006 & 2054.48 & 398.73 & & \\
\hline 2007 & 2893.83 & 398.25 & & \\
\hline 2008 & 3105.15 & 517.58 & & \\
\hline Average & 2222.72 & 343.58 & & \\
\hline SD & 753.04 & 142.46 & & \\
\hline $\mathrm{CV}$ & 33.88 & 41.46 & & \\
\hline
\end{tabular}

(Source: Annual Reports of the Sample Banks from 2004 to 2008)

Table -2 shows that the average non-interest income of the sample banks are 2222.72 and 343.58 respectively during the period under study. The standard deviations of non-interest income of the sample banks are 753.04 and 142.46 and the co-efficient of variations are 33.88 and 41.46 respectively during the period study period. In order to see whether there is any significant difference between the non-interest income of the sample banks and we have conducted paired sample $t$ test using SPSS. The result shows that $t$ value is (6.721) which is significant at 0.003 levels. This indicates that there is significant difference between the non-interest incomes of the sample banks. We observe from the Table that the non-interest income of the Sample \# 1 is higher than the Sample \# 2 during the period under study.

Table \# 3

Table showing the profit before tax of the Sample Banks during the study period (Taka in million)

\begin{tabular}{|c|c|c|c|c|}
\hline Financial Year & Sample \# 1 & Sample \# 2 & t values & SL \\
\hline 2004 & 484.21 & 273.70 & & \\
\cline { 1 - 3 } 2005 & 581.13 & 363.31 & & \\
\hline 2006 & 1058.73 & 499.97 & \multirow{2}{*}{$(2.484)$} & \multirow{2}{*}{0.068} \\
\hline 2007 & 2035.10 & 405.04 & & \\
\cline { 1 - 3 } 2008 & 2828.82 & 865.82 & & \\
\cline { 1 - 3 } Average & 1397.60 & 481.57 & & \\
\hline SD & 1008.78 & 229.69 & & \\
\hline CV & 72.18 & 47.70 & & \\
\hline
\end{tabular}

(Source: Annual Reports of the Sample Banks from 2004 to 2008)

Table -3 shows that the average profit before tax of the sample banks are 1397.60 and 481.57 respectively during the period under study. The standard deviations of profit before tax of the sample banks are 1008.78 and 229.69 and the co-efficient of variations are 72.18 and 47.70 respectively during the period study period. In order to see whether there is any significant difference between the profit before tax of the sample banks and we have 
conducted paired sample $t$ test using SPSS. The result shows that $t$ value is (2.484) which is significant at 0.068 levels. This indicates that there is no significant difference between the profits before tax of the sample banks. We observe from the Table that the profit before tax of the Sample \# 1 is higher than the Sample\# 2 during the period under study.

Table \# 4

Table showing the profit after tax of the Sample Banks during the study period (Taka in million)

\begin{tabular}{|c|c|c|c|c|}
\hline Financial Year & Sample \# 1 & Sample \# 2 & t values & SL \\
\hline 2004 & 170.02 & 155.95 & \multirow{8}{*}{$(2.072)$} & \multirow{8}{*}{0.107} \\
\hline 2005 & 271.67 & 199.82 & & \\
\hline 2006 & 507.49 & 253.40 & & \\
\hline 2007 & 1238.11 & 89.11 & & \\
\hline 2008 & 1517.43 & 479.44 & & \\
\hline Average & 740.94 & 235.54 & & \\
\hline SD & 602.24 & 149.05 & & \\
\hline $\mathrm{CV}$ & 81.28 & 63.28 & & \\
\hline
\end{tabular}

(Source: Annual Reports of the Sample Banks from 2004 to 2008)

Table -4 shows that the average profit after tax of the sample banks are 740.94 and 235.54 respectively during the period under study. The standard deviations of profit after tax of the sample banks are 602.24 and 149.05 and the co-efficient of variations are 81.28 and 63.28 respectively during the period study period. In order to see whether there is any significant difference between the profit after tax of the sample banks and we have conducted paired sample $t$ test using SPSS. The result shows that $t$ value is (2.072) which is significant at 0.107 levels. This indicates that there is no significant difference between the profits after tax of the sample banks. We observe from the Table that the profit after tax of the Sample \# 1 is higher than the Sample \# 2 during the period under study.

Table \# 5

Table showing the credit deposit ratio of the Sample Banks during the study period (Taka in million)

\begin{tabular}{|c|c|c|c|c|}
\hline Financial Year & Sample \# 1 (\%) & Sample \# 2 (\%) & $\mathrm{t}$ values & SL \\
\hline 2004 & 79.83 & 64.33 & \multirow{8}{*}{$(2.028)$} & \multirow{8}{*}{0.112} \\
\hline 2005 & 81.92 & 76.18 & & \\
\hline 2006 & 81.06 & 74.03 & & \\
\hline 2007 & 76.05 & 79.42 & & \\
\hline 2008 & 82.51 & 77.04 & & \\
\hline Average & 80.27 & 74.20 & & \\
\hline SD & 2.57 & 5.85 & & \\
\hline $\mathrm{CV}$ & 3.20 & 7.88 & & \\
\hline
\end{tabular}

(Source: Annual Reports of the Sample Banks from 2004 to 2008)

Table -5 shows that the average credit deposit ratios of the sample banks are 80.27 and 74.20 respectively during the period under study. The standard deviations of the credit deposit ratios of the sample banks are 2.57 and 5.85 and the co-efficient of variations are 3.20 and 7.88 respectively during the period study period. In order to see whether there is any significant difference between the credit deposit ratio of the sample banks and we have conducted paired sample $t$ test using SPSS. The result shows that $t$ value is (2.028) which is significant at 0.112 
levels. This indicates that there is no significant difference between the credit deposit ratios of the sample banks. We observe from the Table that the average credit deposit ratios of the Sample \# 1 are higher than the Sample \# 2 during the period under study.

Table \# 6

Table showing the return on assets ratios of the Sample Banks during the study period (Taka in million)

\begin{tabular}{|c|c|c|c|c|}
\hline Financial Year & Sample \# 1 (\%) & Sample \# 2 $(\%)$ & t values & SL \\
\hline 2004 & 0.48 & 1.16 & & \\
\hline 2005 & 0.74 & 1.18 & & \\
\hline 2006 & 1.19 & 1.26 & \multirow{3}{*}{$0.686)$} & \multirow{3}{*}{0.531} \\
\hline 2007 & 2.40 & 0.34 & & \\
\hline Average & 2.36 & 1.51 & & \\
\hline SD & 1.43 & 1.09 & & \\
\hline CV & 0.90 & 0.44 & & \\
\hline
\end{tabular}

(Source: Annual Reports of the Sample Banks from 2004 to 2008)

Table -6 shows that the average returns on assets ratios of the sample banks are 1.43 and 1.09 respectively during the period under study. The standard deviations of the return on assets ratios of the sample banks are 0.90 and 0.44 and the co-efficient of variations are 62.78 and 40.53 respectively during the period study period. In order to see whether there is any significant difference between the return on assets ratio and we have conducted paired sample $t$ test using SPSS. The result shows that $t$ value is (0.686) which is significant at 0.531 levels. This indicates that there is no significant difference between the return on assets ratios of the sample banks. We observe from the Table that the average returns on assets ratios of the Sample \# 1 are higher than the Sample \# 2 during the period under study.

\section{Table \# 7}

Table showing the return on equity ratios of the Sample Banks during the study period (Taka in million)

\begin{tabular}{|c|c|c|c|c|}
\hline Financial Year & Sample \# 1 (\%) & Sample \# 2 (\%) & t values & SL \\
\hline 2004 & 18.26 & 25.68 & & \\
\cline { 1 - 3 } 2005 & 11.82 & 24.76 & & \\
\cline { 1 - 3 } 2006 & 16.89 & 16.22 & \multirow{3}{*}{$0.375)$} & \multirow{3}{*}{0.727} \\
\hline 2007 & 31.57 & 5.38 & \\
\cline { 1 - 3 } Average & 28.38 & 22.19 & & \\
\hline SD & 21.38 & 18.85 & & \\
\hline CV & 8.28 & 8.38 & \\
\hline
\end{tabular}

(Source: Annual Reports of the Sample Banks from 2004 to 2008)

Table -7 shows that the average returns on equity ratios of the sample banks are 21.38 and 18.85 respectively during the period under study. The standard deviations of the return on equity ratios of the sample banks are 8.28 and 8.38 and the co-efficient of variations are 38.71 and 44.48 respectively during the period study period. In order to see whether there is any significant difference between the return on equity ratios and we have conducted paired sample $t$ test using SPSS. The result shows that $t$ value is $(0.375)$ which is significant at 0.727 levels. This indicates that there is no significant difference between the return on equity 
ratios of the sample banks. We observe from the Table that the average returns on equity ratios of the Sample \# 1 are higher than the Sample \# 2 during the period under study.

\section{SimpLE REGRESSIONS}

In the regression analysis we can examined whether one dependent variables is affected other independent variables. Accordingly we have conducted regression analysis to see weather the profitability of the sample banks have been affected by independent variables. They dependent variables are net profit and return on assets ratio. The independent variables are credit deposit ratio, debt equity ratio, cost of fund and yield on loans and advances.

According our regression model is:

$$
\begin{aligned}
& \mathrm{Y}(\mathrm{t})=\mathrm{a}+\beta 1 \mathrm{X} 1(\mathrm{t})+\varepsilon(\mathrm{t}) \\
& \mathrm{t}=1,2,3 \ldots 4 \\
& \text { Assumptions, } \varepsilon \sim \mathrm{N}(0, \square 2)
\end{aligned}
$$

Here a is the constant;

$\mathrm{Y}(\mathrm{t})$ is the dependent variables for year $\mathrm{t}$

$X(t)$ stands for independent variables for year $t$

$\beta 1$ is the unknown regression coefficient to be estimated; and

$\varepsilon(\mathrm{t})$ is the stochastic term for year $\mathrm{t}$.

So, our null hypotheses are:

$\mathrm{Ho}_{1}$ : The credit deposit ratio does not affect the net profit

Table No. - 8

Net profit Vs Credit deposit ratio

\begin{tabular}{|c|c|c|c|}
\hline SampleCompanies & $\mathbf{R}^{\mathbf{2}}$ & F ratios & Significance Level \\
\hline Sample \# 1 & 0.030 & 0.092 & 0.782 \\
\hline Sample \# 2 & 0.034 & 0.105 & 0.767 \\
\hline
\end{tabular}

(Source: Annual Reports of the Sample Banks from 2004 to 2008)

From Table 8 we see that $\mathrm{R}^{2}$ is $0.030, \mathrm{~F}$ ratios are 0.092 and its significance level is 0.782 of Sample \# 1 and R2 is 0.034 , F ratios are 0.105 and its significance level is 0.767 of Sample \# 2. So, our null hypothesis is accepted which means that credit deposit ratio does not affect the net profit of the sample banks during the period under study.

$\mathrm{Ho}_{2}$ : The debt equity ratio does not affect the net profit

Table No. -9

Net profit Vs Debt equity ratio

\begin{tabular}{|c|c|c|c|}
\hline Sample Companies & $\mathbf{R}^{\mathbf{2}}$ & F ratios & Significance Level \\
\hline Sample \# 1 & 0.511 & 3.136 & 0.175 \\
\hline Sample \# 2 & 0.016 & 0.048 & 0.840 \\
\hline
\end{tabular}

(Source: Annual Reports of the Sample Banks from 2004 to 2008)

From Table 9 we see that $\mathrm{R}^{2}$ is 0.511 , F ratios are 3.136 and its significance level is 0.175 of Sample \# 1 and R2 is 0.016 , F ratios are 0.048 and its significance level is 0.840 of Sample \# 2. So, our null hypothesis is accepted which means that debt equity ratio does not affect the net profit of the sample banks during the period under study. 
$\mathrm{Ho}_{3}$ : The cost of fund does not affect the net profit

Table No. -10

Net profit Vs Cost of fund

\begin{tabular}{|c|c|c|c|}
\hline Sample Companies & $\mathbf{R}^{\mathbf{2}}$ & F ratios & Significance Level \\
\hline Sample \# 1 & 0.828 & 14.456 & 0.032 \\
\hline Sample \# 2 & 0.015 & 0.045 & 0.845 \\
\hline
\end{tabular}

(Source: Annual Reports of the Sample Banks from 2004 to 2008)

From Table 10 we see that $\mathrm{R}^{2}$ is $0.828, \mathrm{~F}$ ratios are 14.456 and its significance level is 0.032 of Sample \# 1 and R2 is 0.015, F ratios are 0.045 and its significance level is 0.845 of Sample \# 2. So, our null hypothesis is rejected of Sample \# 1 and accepted in case of Sample \# 2. Thus we see the cost of fund is an explanatory variable for Sample \# 1 but not for Sample \# 2 during the period under study.

Ho4: The Yield on loans and advances ratio does not affect the net profit

Table No. - 11

Net profit Vs Yield on loans and advances

\begin{tabular}{|c|c|c|c|}
\hline Sample Companies & $\mathbf{R}^{\mathbf{2}}$ & F ratios & Significance Level \\
\hline Sample \# 1 & 0.710 & 7.333 & 0.073 \\
\hline Sample \# 2 & 0.050 & 0.157 & 0.718 \\
\hline
\end{tabular}

(Source: Annual Reports of the Sample Banks from 2004 to 2008)

From Table 11 we see that $\mathrm{R}^{2}$ is 0.710 , F ratios are 7.333 and its significance level is 0.073 of Sample \# 1 and R2 is 0.050 , F ratios are 0.157 and its significance level is 0.718 of Sample \# 2. So, our null hypothesis is accepted which means that yield on loans and advances does not affect the net profit of the sample banks during the period under study.

Ho5: The credit deposit ratio does not affect the return on asset ratios

Table No. - 12

Return on asset ratios Vs Credit deposit ratio ratios

\begin{tabular}{|c|c|c|c|}
\hline Sample Companies & $\mathbf{R}^{\mathbf{2}}$ & F ratios & Significance Level \\
\hline Sample \# 1 & 0.100 & 0.333 & 0.605 \\
\hline Sample \# 2 & 0.100 & 0.333 & 0.605 \\
\hline
\end{tabular}

(Source: Annual Reports of the Sample Banks from 2004 to 2008)

From Table 12 we see that $\mathrm{R}^{2}$ is 0.100 , F ratios are 0.333 and its significance level is 0.605 of Sample \# 1 and R2 is 0.100 , F ratios are 0.333 and its significance level is 0.605 of Sample \# 2. So, our null hypothesis is accepted which means that credit deposit ratio does not affect the return on assets ratios of the sample banks during the period under study.

Ho6: The debt equity ratio does not affect the return on asset ratios

Table No. $-\mathbf{1 3}$

Return on asset ratios Vs Debt equity ratio

\begin{tabular}{|c|c|c|c|}
\hline Sample Companies & $\mathbf{R}^{\mathbf{2}}$ & F ratios & Significance Level \\
\hline Sample \# 1 & 0.589 & 4.308 & 0.130 \\
\hline Sample \# 2 & 0.011 & 0.033 & 0.868 \\
\hline
\end{tabular}

(Source: Annual Reports of the Sample Banks from 2004 to 2008)

From Table 13 we see that $\mathrm{R}^{2}$ is $0.589, \mathrm{~F}$ ratios are 4.308 and its significance level is 0.130 of Sample \# 1 and R2 is 0.011 , F ratios are 0.033 and its significance level is 0.868 of Sample \# 
2. So, our null hypothesis is accepted which means that debt equity ratio does not affect the return on asset ratios of the sample banks during the period under study.

Ho7: The cost of fund does not affect the return on asset ratios

Table No. -14

Return on asset ratios Vs Cost of fund

\begin{tabular}{|c|c|c|c|}
\hline Sample Companies & $\mathbf{R}^{\mathbf{2}}$ & F ratios & Significance Level \\
\hline Sample \# 1 & 0.693 & 6.777 & 0.080 \\
\hline Sample \# 2 & 0.015 & 0.046 & 0.844 \\
\hline
\end{tabular}

(Source: Annual Reports of the Sample Banks from 2004 to 2008)

From Table 14 we see that $\mathrm{R}^{2}$ is 0.693 , F ratios are 6.777 and its significance level is 0.080 of Sample \# 1 and R2 is 0.015 , F ratios are 0.046 and its significance level is 0.844 of Sample \# 2. So, our null hypothesis is accepted which means that cost of fund does not affect the return on asset ratios of the sample banks during the period under study.

Hos: The Yield on loans and advances ratio does not affect the return on asset ratios

Table No. - 15

Return on asset ratios Vs Yield on loans and advances

\begin{tabular}{|c|c|c|c|}
\hline Sample Companies & $\mathbf{R}^{\mathbf{2}}$ & F ratios & Significance Level \\
\hline Sample \# 1 & 0.707 & 7.228 & 0.075 \\
\hline Sample \# 2 & 0.001 & 0.003 & 0.961 \\
\hline
\end{tabular}

(Source: Annual Reports of the Sample Banks from 2004 to 2008)

From Table 15 we see that $\mathrm{R}^{2}$ is $0.707, \mathrm{~F}$ ratios are 7.228 and its significance level is 0.075 of Sample \# 1 and R2 is 0.001 , F ratios are 0.003 and its significance level is 0.961 of Sample \# 2. So, our null hypothesis is accepted which means that yield on loans and advances does not affect the return on asset ratios of the sample banks during the period under study.

\section{MuLTIPLE REgRESSIONS}

Multiple regressions have also been conducted to examine the influence of all the independent variables. We have also conducted multiple regressions to examine whether all the independent variables together affected the dependent variables. Accordingly our multiple regression models is

$$
\begin{aligned}
& \quad y(t)=\alpha+\beta 1 X 1+\beta 2 X 2+\beta 3 X 3+\ldots \ldots \ldots \ldots \ldots \varepsilon(t) \\
& y(t)=\text { Dependent variable } \\
& \alpha=\text { is the constant } \\
& \beta=\text { is the unknown regression coefficient to be estimated. } \\
& X 1, X 2, X 3 \ldots \ldots .=\text { Independent variables } \\
& y(t)=\text { Stochastic term for year } t
\end{aligned}
$$

Hog: The credit deposit ratio, debt equity ratio, cost of fund and yield on loans and advances do not affect the net profit

Table No. -16

Net profit Vs All independent variables

\begin{tabular}{|c|c|c|c|}
\hline Sample Companies & $\mathbf{R}^{\mathbf{2}}$ & F ratios & Significance Level \\
\hline Sample \# 1 & 1.000 & 000 & 000 \\
\hline Sample \# 2 & 0.475 & 0.302 & 0.834 \\
\hline
\end{tabular}

(Source: Annual Reports of the Sample Banks from 2004 to 2008) 
From Table 16 we see that $\mathrm{R}^{2}$ is $1.000, \mathrm{~F}$ ratios are 000 and its significance level is 000 of Sample \# 1 and R2 is 0.475 , F ratios are 0.302 and its significance level is 0.834 of Sample \# 2. So, our null hypothesis is rejected of Sample \# 1 and accepted of Sample \# 2 during the period under study.

$\mathrm{Ho}_{10}$ : The credit deposit ratio, debt equity ratio, cost of fund and yield on loans and advances do not affect the return on assets ratios

Table No. $-\mathbf{1 7}$

Return Vs All independent variables

\begin{tabular}{|c|c|c|c|}
\hline Sample Companies & $\mathbf{R}^{\mathbf{2}}$ & F ratios & Significance Level \\
\hline Sample \# 1 & 1.000 & 000 & 000 \\
\hline Sample \# 2 & 0.731 & 0.907 & 0.629 \\
\hline
\end{tabular}

(Source: Annual Reports of the Sample Banks from 2004 to 2008)

From Table 17 we see that $\mathrm{R}^{2}$ is $1.000, \mathrm{~F}$ ratios are 000 and its significance level is 000 of Sample \# 1 and R2 is 0.731 , F ratios are 0.907 and its significance level is 0.629 of Sample \# 2. So, our null hypothesis is rejected of Sample \# 1 and accepted of Sample \# 2 during the period under study.

\section{CONCLUSION}

The financial condition of the sample banks is satisfactory during the period under study. The average interest income and non-interest income of the sample banks are 3720.91, 1919.03 and 2222.72, 343.58 respectively. The average net profit before tax and net profit after tax are 1397.60, 481.57 and 740.94, 235.54 respectively. The average credit deposit ratio of the sample banks is 74.20 and 80.27 during the period under study. The average return on assets and return on equity ratios is $21.38,18.85$ and $1.43,1.09$ respectively during the period under study. The major findings of the study are: there is significant difference between the interest incomes of the sample banks, there is significant difference between the non-interest incomes of the sample banks, there is no significant difference between the profits before tax of the sample banks, there is no significant difference between the profits after tax of the sample banks, there is no significant difference between the credit deposit ratios of the sample banks, there is no significant difference between the return on assets ratios of the sample banks and there is no significant difference between the return on equity ratios of the sample banks. The study shows mixed results during period under study.

\section{REFERENCES}

Ali, M. S. (2000), Capacity Utilization and Profitability of Sugar Mills in Bangladesh, the Islamic University Studies, Volume 3, No. 2, December

Amandeep (1993), Profits and Profitability in Commercial Banks, New Delhi, Deep and Deep Publications

Annual Reports of National Bank Limited and Jamuna Bank Limited

Baberhee, B., (1990), Financial Policy and Management Accounting, the World Press Private Ltd., Calcutta

Bangladesh Economic Review, (2009) Economic Adviser's Wing, Finance Division, Ministry of Finance, Government of the People's Republic of Bangladesh, June

Block and Hirt (2000), Foundation of Financial Management, 9't Edition, Irwin McGraw- Hill, Boston, USA

Brigham, E. F. and Ehrhardt, M. C, (2000), Financial Management, Thomson, USA 
Gujarati, Damodar N. (1998) Basic Econometrics, (3 ${ }^{\text {rd }}$ Ed.) McGraw - Hill International Editions, Economic Series, Singapore

Hampton, J. J, (2002), Financial Management, Prentice Hall of India New Delhi

Hossain, et. al, (2008), Financial Performance of GrameenPhone Ltd.: An Overview, Islamic University Studies (Part - c), Volume 7, No. 2, June

Husain, S. M. (1990), Profitability Analysis in Mechanized Inland Water Transport of Bangladesh, the Dhaka University Studies, Part - C, Volume - 11 (2)

Kabir, M. H. (2000), Cost Behaviour and Profitability: A Study on Some Company Sugar Mills in Bangladesh, Journal of the Institute of Bangladesh Studies, ISSN 0256-503X, Volume XXIII

Khan, M.Y. and Jain, P.K. (2002) Financial Management, Prentice Hall of India New Delhi

Pandey, I. M., (2007) Financial Management, Vikas Publishing House Pvt. Ltd., Delhi

Rahman and Belal, (1991), Profitability of Urea Fertilizer Sample Companies in Bangladesh: A Comparative Study, Chittagong University Studies, Commerce, Volume 5, No. 1

Saha et. al. (2007), Mercantile Bank Limited: An Effective Measurement by Productivity Indicators, the Islamic University Studies (Part - c), Volume 7. No. 1, December

Saxena and Vashit (1992), Advanced Cost and Management Accounting Text, Sultan Chand and Sons, New Delhi, 1992

Taheruddin M. (1987), Manpower Productivity Situation in Nationalized Commercial Banks in Bangladesh, Bank Parikrama, BIBM, Vol. XIV, Dhaka, No. 3 and 4

Toufic A. Choudhury and Hossain, M. Liakat, (1999) Commercial Bank Restructuring in Bangladesh: From FSRP to CBSP, Bank Parikrama, Vol. XXIV, No. 1, March

\section{CALl for PAPER}

American Journal of Trade and Policy

(AJTP) is an open-access, peer-reviewed interdisciplinary journal which seeks articles from any broad theme of international trade. AJTP features reports on current developments in international trade as well as on related policy issues. The digital online version is published by AJTP, and the hard copy (print) version is published by Asian Business Consortium

(ABC). Web: www.ajtp.us
Engineering International (EI) is a peerreviewed multi-disciplinary international journal devoted to academic advanced research from the engineering arena. It specializes in the publication of comparative thematic issues as well as individual research articles, review essays, and book reviews. Committed to disseminating rigorous scientific research to the widest possible audience, EI is fully and freely accessible on line. Web: www.j-ei.us 